\title{
Comparative Proteome Analysis of Celastrol-Treated Helicobacter pylori
}

\author{
Sa-Hyun Kim ${ }^{\dagger}$ \\ Department of Clinical Laboratory Science, Semyung University, Jecheon 27136, Korea
}

\begin{abstract}
Various preclinical and clinical trials have been conducted the efficacy of celastrol. In data presented in the current manuscript is the first trial to inhibit Helicobacter pylori with celastrol. In this study, the quantitative change of various H. pylori proteins including CagA and VacA by the anti-bacterial effect of celastrol was determined. The anti-H. pylori effects of celastrol was investigated by performing 2-dimensional electrophoresis and additional supporting experiments. After 2-dimensional electrophoresis analysis, spot intensities were analyzed and then each spot was identified using matrix assisted laser desorption ionization-time of flight mass spectrometry (MALDI-TOF-MS) or peptide sequencing using Finnigan LCQ ion trap mass spectrometer (LC-MS/MS). The results show that celastrol has multiple effects on protein expression in H. pylori.
\end{abstract}

Key Words: Helicobacter pylori, 2 dimensional electrophoresis, Celastrol, MALDI-TOF-MS

Recently, interest in celastrol has renewed again as a new candidate drug for obesity and various chronic diseases (Cascao et al., 2017). Celastrol has been reported primarily to exhibit inhibitory effects on several cancers, such as breast cancer, prostate cancer and colorectal cancer (Shrivastava et al., 2015; Guo et al., 2015; Lin et al., 2016). And other preclinical and clinical trials on various purpose with celastrol have been continued till now (Fig. 1). This is the first trial to inhibit Helicobacter pylori with celastrol. Here we demonstrated the preliminary clues for showing anti- $H$. pylori effects of celastrol by performing 2-dimensional electrophoresis and some supporting experiments. To suggest celastrol as a potential cure drug for H. pylori infection, we tried to find the relationship between the quantitative expression level changes of human gastrointestinal disease-responsible proteins. In our data, the expression levels of some virulence factors were inhibited, while some other factors which were related to bacterial cell survival were increased as 'compensatory hyperincrease'.

In H. pylori, cytotoxin-associated protein $\mathrm{A}(\mathrm{Cag} \mathrm{A})$ and vacuolating cytotoxic protein $\mathrm{A}$ ( $\mathrm{Vac} \mathrm{A})$ have been reported as the most representative virulence factors because they are responsible for gastric or duodenal cancer development directly (Censini et al., 1996; Cover et al., 1993). While, in our results of 2-dimensional electrophoresis (2-DE), metabolic proteins like as AimE, FtnA, AcnB, type III restriction enzyme R protein, HSP90, UreB, OorA, including toxic protein CagA and VacA were showed quantitative changes when celastrol were treated to $H$. pylori culture. In this study, 2-dimensional electrophoresis (2-DE) and protein identification technique was used to analyze the effect of celastrol on the expression of various $H$. pylori proteins.

In this study, celastrol (Extrasynthese; Lyon, France) was dissolved in sterile dimethyl sulfoxide (DMSO; Sigma Aldrich, St. Louis, MO, USA) as a $100 \mathrm{mM}$ stock solution and stored at $-80^{\circ} \mathrm{C}$ prior to use. And Helicobacter pylori

* Received: December 5, 2017 / Revised: December 18, 2017 / Accepted: December 18, 2017

${ }^{\dagger}$ Corresponding author: Sa-Hyun Kim. Department of Clinical Laboratory Science, Semyung University, Jecheon 27136, Korea.

Tel: +82-43-649-1624, Fax:+82-43-649-7361, e-mail: science4us@semyung.ac.kr

(C) The Korean Society for Biomedical Laboratory Sciences. All rights reserved.

(c) This is an Open Access article distributed under the terms of the Creative Commons Attribution Non-Commercial License (http://creativecommons.org/licenses/by-nc/3.0/) which permits unrestricted non-commercial use, distribution, and reproduction in any medium, provided the original work is properly cited. 
reference strain 60190 was purchased from American Type Cell Collection (ATCC; Manassas, VA, USA). Bacteria were maintained under microaerophilic conditions at $37^{\circ} \mathrm{C}$ on Brucella agar plates (Becton-Dickinson, Braintree, MA, USA) supplemented with 10\% fetal bovine serum (FBS; Gibco,

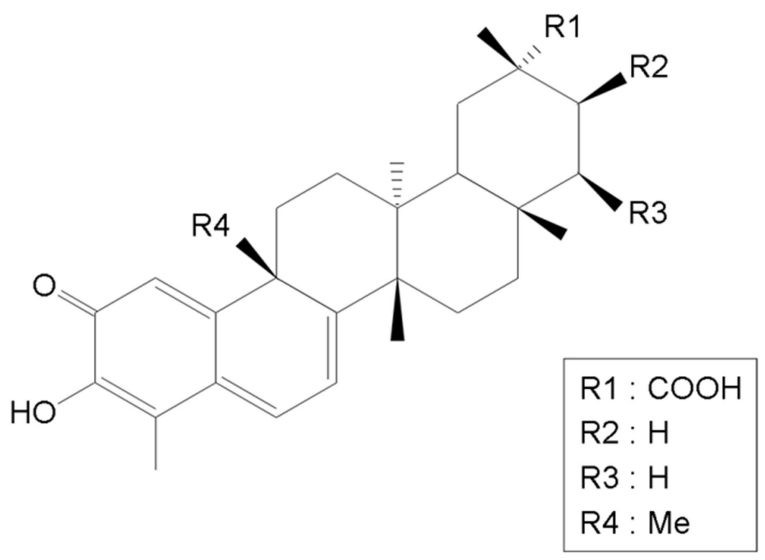

Fig. 1. Chemical structure of celastrol.
Long Island, NY, USA). For experiments, H. pylori were cultured in Mueller-Hinton broth (Becton-Dickinson) with (3 $\mu \mathrm{M}$, under the minimum inhibitory concentration) or without celastrol containing 10\% FBS under microaerophilic condition for $3 \sim 4$ days at $37^{\circ} \mathrm{C}$ and $100 \%$ humidity (Fig. 2).

To perform the proteomics study, the harvested samples were suspended in $0.5 \mathrm{ml}$ of $50 \mathrm{mM}$ Tris buffer containing $7 \mathrm{M}$ urea, $2 \mathrm{M}$ thiourea, 4\% (w/v) CHAPS, and $16 \mu \mathrm{l}$ protease inhibitor cocktail (Roche Molecular Biochemicals, Indianapolis, IA, USA). For 2-DE analysis, pH 4 7 IPG strips (Amersham, Pittsburgh, PA, USA) were used. The 2-DE separation was performed on $8 \sim 16 \%(\mathrm{v} / \mathrm{v})$ linear gradient SDS-polyacrylamide gels. Protein spot detection and 2DE pattern matching were carried out using ImageMaster ${ }^{\mathrm{TM}}$ 2DE Platinum software (Amersham). For comparison of protein spot densities between control and treated samples, more than 20 spots throughout all gels were correspondingly landmarked and normalized. The quantified spots of candidate proteins were compared with the aid of histograms.
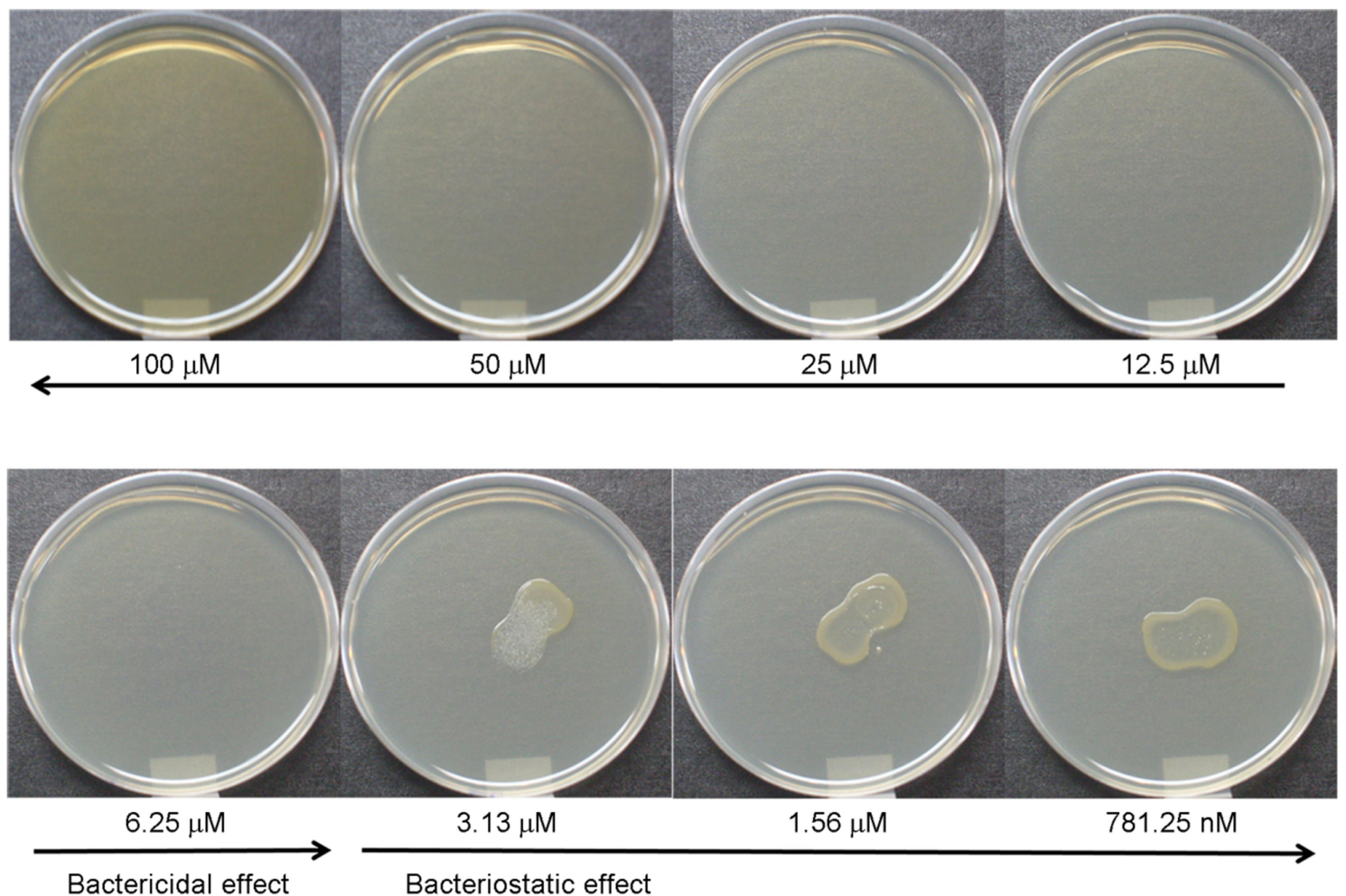

Fig. 2. Minimum inhibitory concentration of celastrol to $H$. pylori. 
For ensuring the reproducibility of 2-DE experiments, each sample was analyzed in triplicate. The procedure for in-gel digestion of protein spots from Coomassie Blue stained gels was carried out and these procedures were performed by ProteomeTech (Seoul, South Korea). In brief, protein spots were excised from stained gels and cut into pieces. The excised protein spots from a silver stained gel were cut into pieces and in-gel digested with trypsin.

To analyze the peptides, mass measurement of tryptic peptides was carried out with a Voyager-DE STR mass spectrometer (PerSpective Biosystems, Bedford, MA, USA). Close external calibration was performed for every samples with calibration mixtures. The proteins were identified by peptide mass fingerprinting (PMF) searching, against the SwissProt and NCBI databases, using the search program ProFound (http://129.85.19.192/profound_bin/WebProFound.exe, Rockefeller University, Version 4.10.5), MASCOT (http:// www.matrixscience.com/cgi/search form.pl?FORMVER= 2\&SEARCH=PMF), or MS-Fit (http://prospector.ucsf.edu/ ucsfhtml4.0/msfit.htm, University of California San Francisco, Version 4.0.5).

To identify the results, tryptic peptides were separated and analyzed using reversed phase capillary HPLC directly coupled to a Finnigan LCQ ion trap mass spectrometer (LCMS/MS). For tandem mass spectrometry, a full mass scan range mode was $\mathrm{m} / \mathrm{z}=450 \sim 2,000 \mathrm{Da}$. The individual spectra from MS/MS were processed using the TurboSEQUEST software (Thermo Quest, San Jose, CA). The generated peak list files were used to query either MSDB database or NCBI using the MASCOT program (http://www.matrixscience.com). Only significant hits as defined by MASCOT probability analysis were considered initially.

Numerous protein spots (approximately 200) per silverstained gel were analyzed by the PDQUEST program. Then

Table 1. Representatively increased proteins of H. pylori 60190 strain in the structure-bound fraction when H. pylori was exposed to celastrol

\begin{tabular}{|c|c|c|c|c|c|c|}
\hline \multirow{2}{*}{$\begin{array}{l}\text { Spot } \\
\text { No. }\end{array}$} & \multicolumn{2}{|r|}{ Protein $^{\text {a) }}$} & \multicolumn{4}{|c|}{ 2-DE data ${ }^{\text {b) }}$} \\
\hline & $\begin{array}{l}\text { TIGR locus } \\
\text { name }\end{array}$ & Protein name & $\mathrm{p} I / M_{\mathrm{r}}$ & $\begin{array}{l}\text { Protein-change ratio }(\%)^{\mathrm{c})} \\
\text { after } \mathrm{C} 3 \mathrm{G} \text { treatment }\end{array}$ & $\begin{array}{l}\text { Standard }^{\mathrm{d})} \\
\text { deviation }\end{array}$ & Reference \\
\hline 1 & HP0786 & $\begin{array}{l}\text { Preprotein translocase subunit } \\
\operatorname{Sec} A(\operatorname{Sec} A)\end{array}$ & $6.12 / 99,207$ & -146.90 & 1.73 & Kim et al., 2015 \\
\hline 2 & HP0072 & Urease subunit beta (UreB) & $6.09 / 61,645$ & - 2099.90 & 3.23 & $\begin{array}{l}\text { Backert et al., } \\
2005\end{array}$ \\
\hline 3 & HP0809 & $\begin{array}{l}\text { Flagellar basal body protein } \\
\text { FliL (FliL) }\end{array}$ & $5.41 / 55,134$ & 877.53 & 1.74 & Kim et al., 2015 \\
\hline 4 & HР0210 & Heat shock protein 90 (Hsp90) & $5.73 / 71,230$ & -4863.70 & 4.93 & Kim et al., 2015 \\
\hline 5 & HР0779 & $\begin{array}{l}\text { Aconitate hydratase AcnB } \\
\text { (AcnB) }\end{array}$ & $6.44 / 118,230$ & -4237.40 & 13.49 & $\begin{array}{l}\text { Backert et al., } \\
2015\end{array}$ \\
\hline 6 & HР0294 & $\begin{array}{l}\text { Acylamide amidohydrolase } \\
\text { (AmiE) }\end{array}$ & $7.28 / 37,689$ & -434.36 & 16.04 & This study \\
\hline 7 & HP0589 & $\begin{array}{l}\text { 2-oxoglutarate-acceptor } \\
\text { oxidoreductase subunit (OorA) }\end{array}$ & $6.94 / 41,448$ & -4503.70 & 9.87 & This study \\
\hline 8 & HP0389 & $\begin{array}{l}\text { Iron-dependent superoxide } \\
\text { dismutase (SodB) }\end{array}$ & $6.17 / 24,617$ & -8120.30 & 13.68 & Park et al., 2016 \\
\hline 9 & HP0653 & $\begin{array}{l}\text { Non-heme iron-containing } \\
\text { ferritin (FtnA) }\end{array}$ & $4.86 / 19,302$ & -179.13 & 37.32 & This study \\
\hline
\end{tabular}

a) Protein designation according to H. pylori strain, NCBI (http://www.ncbi.nlm.nih.gov/), KEGG database (http://www.genome.jp/kegg/)

b) According to peptide mass fingerprinting (PMF) data were obtained from Figure 1.

c) The ratio of protein-change amount was calculated as follows:

$$
\text { change ratio }(\%)=\frac{\Delta \text { value }(\text { protein amount } \mathrm{w} / \text { celastrol }- \text { protein amount } \mathrm{w} / \mathrm{o} \text { celastrol })}{\Delta \text { value }(\text { protein amount } \mathrm{w} / \mathrm{o} \text { C3G) }} \times 100
$$

d) Standard deviation of protein-change ratio in each spot was obtained from repeated five independent 2-DE analysis. 
Table 2. Representatively decreased proteins of H. pylori 60190 strain in the structure-bound fraction when H. pylori was exposed to celastrol

\begin{tabular}{|c|c|c|c|c|c|c|}
\hline \multirow[b]{2}{*}{$\begin{array}{l}\text { Spot } \\
\text { No. }\end{array}$} & \multicolumn{2}{|r|}{ Protein $^{\text {a) }}$} & \multicolumn{4}{|c|}{ 2-DE data ${ }^{b)}$} \\
\hline & $\begin{array}{l}\text { TIGR locus } \\
\text { name }\end{array}$ & Protein name & $\mathrm{p} I / M_{\mathrm{r}}$ & $\begin{array}{c}\text { Protein-change ratio }(\%)^{\mathrm{c})} \\
\text { after } \mathrm{C} 3 \mathrm{G} \text { treatment }\end{array}$ & $\begin{array}{l}\text { Standard }^{\mathrm{d})} \\
\text { deviation }\end{array}$ & Reference \\
\hline 1 & HP0547 & $\begin{array}{l}\text { Cytotoxin-associated gene } \\
\text { protein A (CagA) fragment }\end{array}$ & $5.75 / 81,500$ & +4784.72 & 9.98 & $\begin{array}{l}\text { González et al., } \\
2013\end{array}$ \\
\hline 2 & HP0887 & $\begin{array}{l}\text { Vacuolating cytotoxic protein } \\
\text { A(VacA) fragment }\end{array}$ & $6.65 / 87,970$ & +2305.02 & 3.84 & $\begin{array}{l}\text { Backert et al., } \\
2005\end{array}$ \\
\hline 3 & HP0072 & Urease subunit beta (UreB) & $6.09 / 61,645$ & +1546.73 & 2.48 & Kim et al., 2015 \\
\hline 4 & HР0294 & $\begin{array}{l}\text { Acylamide amidohydrolase } \\
\text { (AmiE) }\end{array}$ & $7.28 / 37,689$ & +653.95 & 69.09 & This study \\
\hline 5 & HP0589 & $\begin{array}{l}\text { 2-oxoglutarate-acceptor } \\
\text { oxidoreductase subunit (OorA) }\end{array}$ & $6.94 / 41,448$ & +445.27 & 23.22 & This study \\
\hline 6 & HP0010 & $\begin{array}{l}\text { Heat-shock protein } 60 \text { subunit } \\
(\text { GroEL }) \text { ) }\end{array}$ & $6.17 / 20,188$ & +2492.67 & 1.44 & Park et al., 2016 \\
\hline
\end{tabular}

a) Protein designation according to H. pylori strain, NCBI (http://www.ncbi.nlm.nih.gov/), KEGG database (http://www.genome.jp/kegg/).

b) According to peptide mass fingerprinting (PMF) data were obtained from Figure 1.

c) The ratio of protein-change amount was calculated as follows:

$$
\text { change ratio }(\%)=\frac{\Delta \text { value }(\text { protein amount } \mathrm{w} / \text { celastrol }- \text { protein amount } \mathrm{w} / \mathrm{o} \text { celastrol })}{\Delta \text { value }(\text { protein amount } \mathrm{w} / \mathrm{O} \mathrm{C} 3 \mathrm{G})} \times 100
$$

d) Standard deviation of protein-change ratio in each spot was obtained from repeated five independent 2-DE analysis.

methodologically the selected each protein spot was relatively evident than others in the 2-DE images and were identified by peptide mass fingerprinting using MALDITOF-MS or by peptide sequencing using LC-MS/MS (Table 1, 2). All the analyzed 2-DE spot profiles of H. pylori 60190 strain among total spot profiles of protein changes were compared to reference data (Choi et al., 2002; Jungblut et al., 2000). The displayed protein spots in this study were focused on the relation with clinical diseases, such as chronic gastritis, gastric ulcers, or gastric adenocarcinoma (Park et al., 2006; Backert et al., 2005).

We could find meaningful nine protein spots which the expression level was decreased by celastrol treatment. They were preprotein translocase subunit $\operatorname{Sec} A(\operatorname{Sec} A)$, Ulurease subunit beta (UreB), flagellar basal body protein FliL (FliL), heat shock protein 90 (Hsp90), aconitate hydratase AcnB (AcnB), acylamide amidohydrolase (AmiE), 2-oxoglutarateacceptor oxidoreductase subunit (OorA), iron-dependent superoxide dismutase (SodB), and non-heme iron-containing ferritin (FtnA) (Fig. 3 and 4).

SecA; Sec-related proteins are associated with the type V secretion system (T5SS) of H. pylori (Cover and Blanke,
2005). It has been reported that VacA secretion is SecAdependent (Cover and Blanke, 2005; Shaffer et al., 2011). This suggests that the decreased SecA expression might affect the accumulation of VacA in cell. We could also find such a phenomenon in our data (Fig. 3 and 4).

UreB; Urease subunit beta with subunit alpha involve in critical role of $H$. pylori colonizing in acidic gastric environment (Park et al., 2006). It has been reported that $H$. pylori ureases produces alkaline ammonia by degrading urea. $H$. pylori can survive in acidic gastric environment thereby neutralizing acidic gastric environment with this alkaline substance. If the expression level of UreB was decreased by celastrol treatment, it showed that celastrol might be a potential inhibitor for H. pylori (Fig. 3 and 4).

FliL; although the function of FliL in $H$. pylori is not clear yet, it has been reported that FliL is essential for swarming but not for swimming or motility in genus Proteus (Lee et al., 2013). It is thought that H. pylori FliL is also a transmembrane protein located adjacent to the basal body of its flagellar structure (Lee and Belas, 2015). When H. pylori was exposed to celastrol if the expression of FliL was decreased, it might be an expected positive result (Fig. 3 and 4). 
(A)

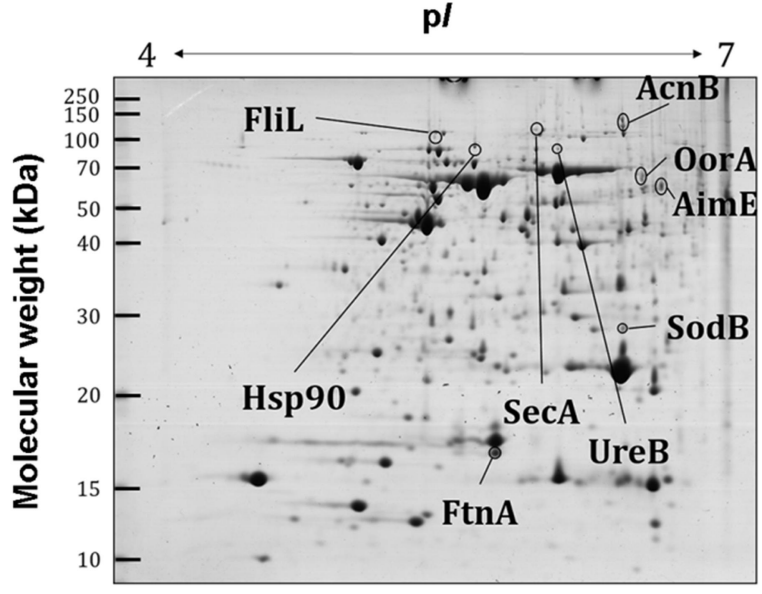

HP 60190

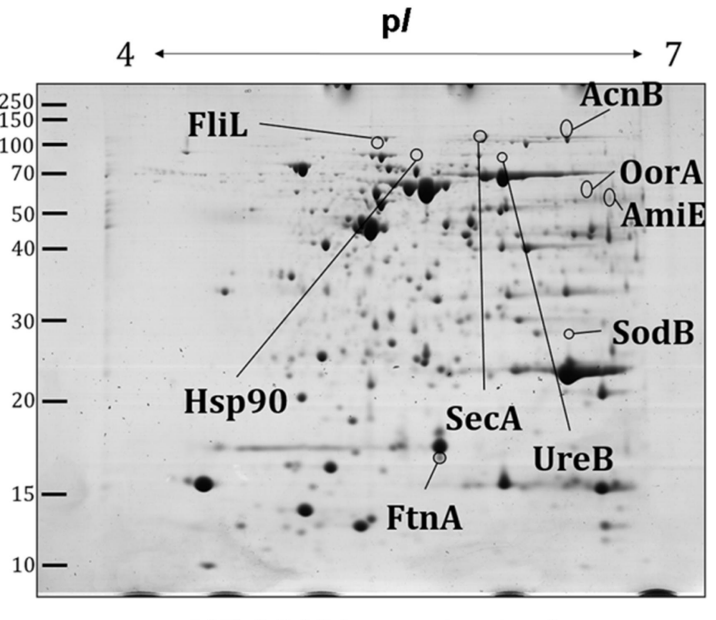

HP $60190+$ celastrol

B

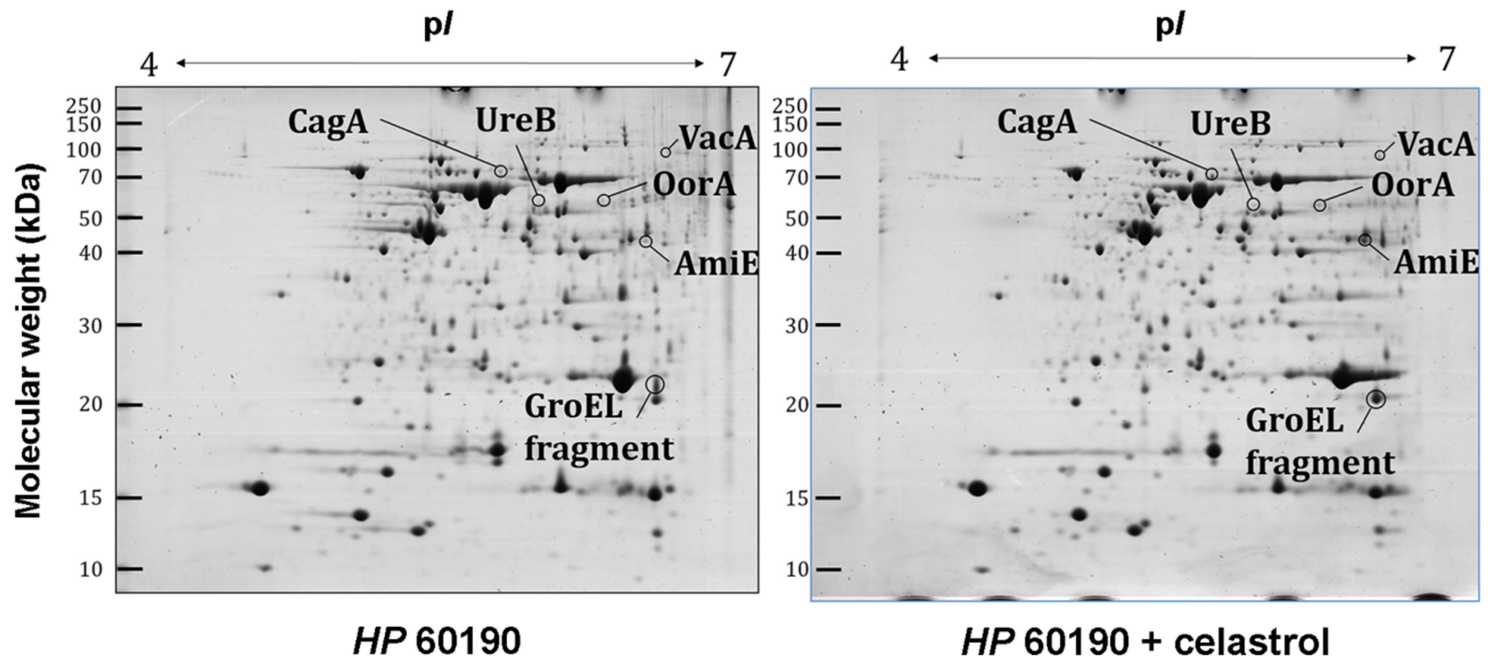

Fig. 3. A representative two-dimensional gel-electrophoresis map of the whole-cell protein ( $30 \mu \mathrm{g})$ of H. pylori 60190 standard strain isolate. This showed the changed expression levels of various proteins when $H$. pylori was exposed to $3 \mu \mathrm{M}$ of celastrol for three days. The spots were identified by MALDI-TOF-MS or TOF-MS. Molecular size markers are shown on the left in $\mathrm{kDa}$. (A) Analysis of quantitatively decreased protein spots. (B) Analysis of quantitatively increased protein spots.

Hsp90; H. pylori Hsp90 showed decrease in its expression with celastrol in our data (Fig. 3 and 4), although its function in H. pylori is not known yet.

AcnB, AmiE, OorA, SodB and FtnA; these molecules are important metabolic components in $H$. pylori. Thus, it was thought that the growth of $H$. pylori might be suppressed thereby inducing metabolic malfunction in $H$. pylori by celastrol treatment (Fig. 3 and 4).

Some other six proteins which are related to cell survival or pathogenicity were showed increased as irony. Because the celastrol was treated to $H$. pylori culture under the minimum inhibitory concentration $(3 \mu \mathrm{M})$, it was thought that bacterial cells might fight for survival when they were exposed to celastrol. Here we explained this as 'compensatory hyperincrease'.

Cytotoxin-associated gene protein A (CagA), Vacuolating cytotoxic protein A (VacA), UreB, AmiE, OorA, and Heatshock protein 60 subunit (GroEL) were showed increased 
(A)

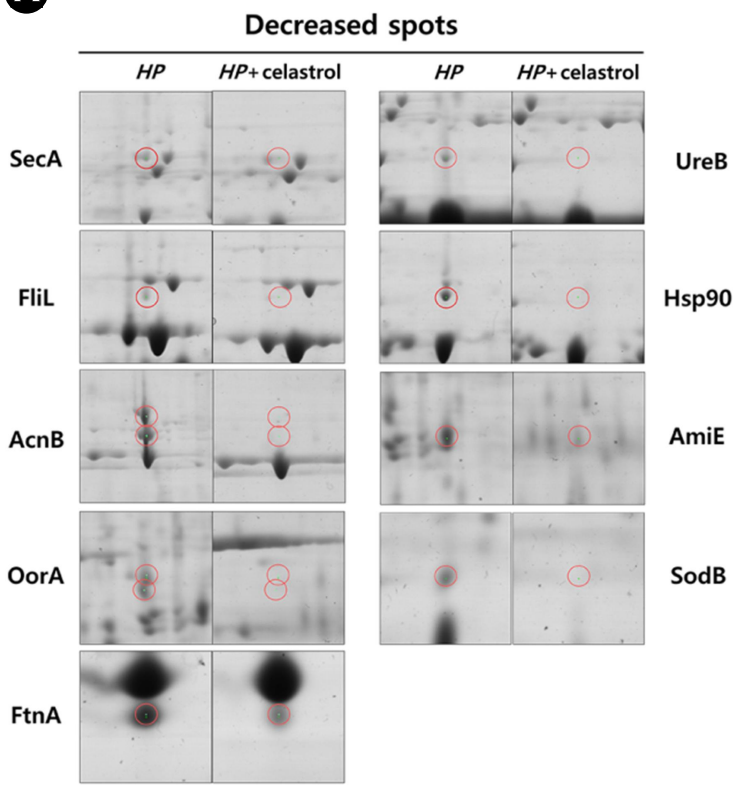

B

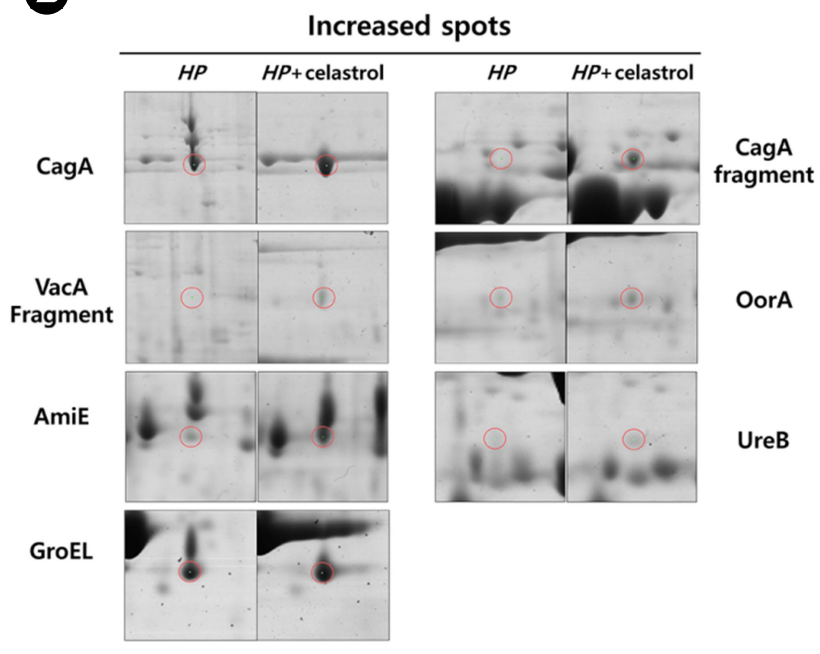

Fig. 4. Quantitatively changed protein spots and protein identification. (A) SecA, UreB, FliL, Hsp90, AcnB, AmiE, OorA, SodB, FtnA were quantitatively decreased when celastrol was treated to H. pylori 60190. (B) CagA, VacA were accumulated in periplasmic or in cytoplasmic space of $H$. pylori 60190 when celastrol was treated. And OorA. AmiE, UreB, GroEL were also increased when celastrol was treated to same conditions. It was thought as 'compensatory hyperincrease' to recover the chemical stress.

protein expression level when celastrol was treated. It was thought that CagA, VacA were accumulated in periplasmic or in cytoplasmic space of $H$. pylori 60190.

CagA and VacA; they toxin-like proteins of $H$. pylori are strongly responsible for significantly increased risk of the development of gastric disorders like chronic gastric inflammation, ulcers, various cancers (Censini et al., 1996). Although CagA accumulation in cell could not be explained in the aspect of its mechanism, here, in our data, VacA accumulation in cell could be explained readily. Because VacA secretion is regulated by SecA-dependent $\mathrm{T} 5_{\mathrm{a}} \mathrm{SS}$, as shown prior, if SecA was decreased by exposing celastrol, its accumulation in cell would be induced (Kim et al., 2014) (Fig. 3 and 4).

Now, the complete genome sequences of $H$. pylori strains 26695 and J99 had been reported (Alm et al., 1999; Tomb et al., 1997), however the information is imperfect. Thus it is thought that the additional genomic or proteome information like this should be accumulated for further research.

\section{ACKNOWLEDGMENTS}

This paper was supported by the Semyung University Research Grant of 2017.

\section{CONFLICT OF INTEREST}

No conflicts of interest, financial or otherwise, are declared by the authors.

\section{REFERENCES}

Alm RA, Ling LS, Moir DT, King BL, Brown ED, Doig PC, Smith DR, Noonan B, Guild BC, deJonge BL, Carmel G, Tummino PJ, Caruso A, Uria-Nickelsen M, Mills DM, Ives C, Gibson R, Merberg D, Mills SD, Jiang Q, Taylor DE, Vovis GF, Trust TJ. Genomic-sequence comparison of two unrelated isolates of the human gastric pathogen Helicobacter pylori. Nature. 1999. 14: 176-180.

Backert S, Kwok T, Schmid M, Selbach M, Moese S, Peek RM Jr, König W, Meyer TF, Jungblut PR. Subproteomes of soluble and structure-bound Helicobacter pylori proteins analyzed by two-dimensional gel electrophoresis and mass spectrometry. 
Proteomics. 2005. 5: 1331-1345.

Cascao R, Fonseca JE, Moita LF. Celastrol: a spectrum of treatment opportunities in chronic diseases. Frontiers of Medicine. 2017. 15: 69.

Censini S, Lang C, Crabtree JE, Ghiara P, Borodovsky M, Rappuoli R, Covacci A. cag pathogenicity island of Helicobacter pylori encodes type I-specific and disease-associated virulence factors. Proceedings of the National Academy of Sciences of the United States of America. 1996. 93: 14648-14653.

Cover TL, Cao P, Lind CD, Tham KT, Blaser MJ. Correlation between vacuolating cytotoxin production by Helicobacter pylori isolates in vitro and in vivo. Infection and Immunity. 1993. 61: 5008-5012.

Cover TL, Blanke SR. Helicobacter pylori VacA, a paradigm for toxin multifunctionality. Nature Reviews of Microbiology. 2005. 3: $320-332$.

González L, Marrero K, Reyes O, Rodríguez E, Martínez L, Rodríguez BL. Cloning and expression of a recombinant CagA-gene fragment of Helicobacter pylori and its preliminary evaluation in serodiagnosis. Biomedica. 2013. 33: 546-553.

Guo J, Huang X, Wang H, Yang H. Celastrol induces autophagy by targeting AR/miR-101 in prostate cancer cells. PLOS One. 2015. 10: $\mathrm{e} 0140745$.

Jungblut PR, Bumann D, Haas G, Zimmy-Arndt U, Holland P, Lamer S, Siejak F, Aebischer A, Meyer TF. Comparative proteome analysis of Helicobacter pylori. Molecular Microbiology. 2000. 36: 710-725.

Kim SH, Kim JB. Comparative proteome analysis of cyanidine 3-O glucoside treated Helicobacter pylori. Biomedical Science Letters. 2015. 21: 233-240.

Lee YY, Belas R. Loss of FliL alters Proteus mirabilis surface sensing and temperature-dependent swarming. Journal of Bacteriology. 2015. 197: 159-173.

Lee YY, Patellis J, Belas R. Activity of Proteus mirabilis FliL is viscosity dependent and requires extragenic DNA. Journal of Bacteriology. 2013. 195: 823-832.
Lin L, Sun Y, Wang D, Zheng S, Zhang J, Zheng C. Celastrol ameliorates ulcerative colitis-related colorectal cancer in mice via suppressing inflammatory responses and epithelialmesenchymal transition. Frontiers in Pharmacology. 2016. 13: 320 .

Park JW, Song JY, Lee SG, Jun JS, Park JU, Chung MJ, Ju JS, Nizamutdinov D, Chang MW, Youn HS, Kang HL, Baik SC, Lee WK, Cho MJ, Rhee KH. Quantitative analysis of representative proteome components and clustering of Helicobacter pylori clinical strains. Helicobacter. 2006. 11: 533-543.

Shaffer CL, Gaddy JA, Loh JT, Johnson EM, Hill S, Hennig EE, McClain MS, McDonald WH, Cover TL. Helicobacter pylori exploits a unique repertoire of type IV secretion system components for pilus assembly at the bacteria-host cell interface. PLOS Pathogen. 2011. 7: e1002237.

Shrivastava S, Jeengar MK, Reddy VS, Reddy GB, Naidu VG. Anticancer effect of celastrol on human triple negative breast cancer: possible involvement of oxidative stress, mitochondrial dysfunction, apoptosis and PI3K/Akt pathways. Experimental and Molecular Pathology. 2015. 98: 313-327.

Tomb JF, White O, Kerlavage AR, Clayton RA, Sutton GG, Fleischmann RD, Ketchum KA, Klenk HP, Gill S, Dougherty BA, Nelson K, Quackenbush J, Zhou L, Kirkness EF, Peterson S, Loftus B, Richardson D, Dodson R, Khalak HG, Glodek A, McKenney K, Fitzegerald LM, Lee N, Adams MD, Hickey EK, Berg DE, Gocayne JD, Utterback TR, Peterson JD, Kelley JM, Cotton MD, Weidman JM, Fujii C, Bowman C, Watthey L, Wallin E, Hayes WS, Borodovsky M, Karp PD, Smith HO, Fraser CM, Venter JC. The complete genome sequence of the gastric pathogen Helicobacter pylori. Nature. 1997. 7: 539-547.

https://doi.org/10.15616/BSL.2017.23.4.395

Cite this article as: $\mathrm{SH}$ Kim. Comparative Proteome Analysis of Celastrol-Treated Helicobacter pylori. Biomedical Science Letters. 2017. 23: 395-401. 